\title{
Request for Assistance in Preventing Deaths and Injuries from Excavation Cave-ins
}




\section{DISCLAIMER}

Mention of the name of any company or product does not constitute endorsement by the National Institute for Occupational Safety and Health.

DHHS (NIOSH) Publication No. 85-110

\section{Additional copies of this alert are available from}

Publications Dissemination, DSDTT

National Institute for Occupational Safety and Health 4676 Columbia Parkway

Cincinnati, Ohio 45226

(513) $841-4287$ 
BIBLIOGRAPHIC INFORMATION

PB 86-121415

Request for Assistance in Preventing Deaths and Injuries from Excavation Cave-ins.

Jul 85

PERFORMER: National Inst. for Occupational Safety and Health, Cincinnati, $\mathrm{OH}$. DHHS / PUB / NIOSH-85-110

The principal objective of the investigations undertaken by NIOSH as part of its Fatal Accident Circumstances and Epidemiology (FACE) Project is to determine what factors enabled the fatality to occur. The goal is to learn how such fatalities can be prevented. In this context, whether or not an operation was 'in compliance' with existing standards is but one of many variables which may or may not have contributed to the fatality. However, in the course of investigations reported here, it became obvious that full compliance with relevant OSHA standards or application of the NBS/NIOSH recommended work practices would probably have prevented each fatality.

KEYWORDS: *Accident prevention, *Industrial accidents, *occupational safety and health.

Available from the National Technical Information Service, SPRINGFIELD，VA. 22161

PRICE CODE: PC A02/MF A0I 

REQUEST FOR ASSISTANCE IN PREVENTING

DEATHS AND INJURIES FROM EXCAVATION CAVE-INS

\section{BACKGROUND}

Excavation cave-ins cause serious and of ten fatal injuries to workers in the United States. An analysis by the National Institute for Occupational Safety and Health (NIOSH) of workers' compensation claims for 1976 to 1981 [1] in the Supplementary Data System of the Bureau of Labor Statistics suggests that excavation cave-ins caused about 1,000 work-related injuries each year. of these, about 140 result in permanent disability and 75 in death. Thus, this type of incident is a major cause of deaths associated with work in excavations and accounts for nearly $1 \%$ of all annual work-related deaths in the nation.

\section{CASE REPORTS}

As part of the Fatal Accident Circumstances and Epidemiology (FACE) Project of NIOSH, four deaths caused by excavation cave-ins were recently investigated. Synopses of these cases follow:

Case 非:

A 53-year-old laborer employed by a clty sewer department entered an 11 1/2-foot-deep unshored, vertical-walled, manhole excavation in order to lower and level the area where the manhole foundation was to be set. As he was leaving the excavation after completing this task, one wall collapsed burying him completely and killing him.

\section{Case \#2:}

A 22-year-old laborer was manually digging a dry well and a trench 8 feet deep for a drainage pipe connection. None of the walls of the excavated areas were shored or sloped to a safe angle of repose, 1.e., the greatest angle above the horizontal plane at which a materlal will lie without sliding. As the worker was digging the trench, one wall collapsed covering him with 6 feet of soll and killing him. 
Page 2 - Request for Assistance in Preventing Deaths and Injuries from Excavation Cave-ins

\begin{abstract}
Case \#3:
245 -year-old construction "lead man" was shoveling loose dirt -... the bottom of a 21-foot-deep unshored, vertical-walled excavation to accommodate placement of a fabricated trench shield. Soll began falling from a side wall; as the worker attempted to leave the site, the soil "gave way" entirely
\end{abstract} covering and killing him.

Case \#4:

A 32-year-old construction field foreman was standing in an unshored, vertical-walled excavation approximately 7 feet deep. One wall caved in, knocking the foreman down, entirely covering him with soll and killing him.

\title{
APPROPRIATE STANDARDS AND RECOMMENDED WORK PRACTICES
}

Standards promulgated by the Occupational Safety and Health Administration (OSHA) establish specific requirements intended to protect workers in excavations and trenches (29 CFR 1926.651 and .652, respectively). Basically, these standards require that walls and faces of all excavations in which workers are potentially exposed to danger from moving ground be guarded by a shoring system, safe sloping of the ground, or equivalent means of protection such as trench shields or boxes. However, the standards are applicable only to trenches 5 feet or more in depth.

A table published in 29 CFR 1926.652 indicates the required horizontal-tovertical ratio for sloping the sides of excavations as they relate to specific types of soil. These requirements are intended to approximate, for each soll type, the safe angle of repose. The standards also define minimum requirements for shoring of trenches for various classifications of solls. The standards require additional shoring and bracing procedures when excavations or trenches are located adjacent to previously backfilled excavations or where excavations are subjected to vibrations from rallroad or highway traffic, the operation of machinery, or other sources.

A major issue surrounding existing OSHA standards for excavations, trenching, and shoring is the classification of solls. Soll classification provides an empirical estimation of the soll's stability. If the potential for cave-ins or other dangerous movements of ground is thought to exist, appropriate decisions to provide adequate protection must be reached. Regarding soil classification, however, critics have described the existing standards as vague and confusing and subject to dangerously varlable interpretation [ 2 ]. 
Page 3 - Request for Assistance in Preventing Deaths and Injuries from Excavation Cave-ins

Recently, the National Bureau of Standards (NBS) and NIOSH jointly published Development of Draft Construction Safety Standards for Excavations, DHHS (NIOSH) Publication No. 83-103 [3]. This document recommends establishing a requirement to provide protection in excavations 5 feet deep or greater regardless of soll type. It also presents a simplified soil classification system for use in determining appropriate side-sloping requirements and for calculating the lateral soil pressures imposed on shoring systems.

\section{APPLICATION OF EXISTING STANDARDS AND RECOMMENDED WORK PRACTICES}

In the fatal incldents described above, none of the excavations were found to incorporate those protective measures specified in applicable OSHA Standards or the joint NBS/NIOSH publication. Table 1 suggests that compliance with existing regulations or adherence to recommended work practices might have prevented important causative circumstances in each of the four fatal incidents.

\section{CONCLUSION}

The principal objective of the investigations undertaken by NIOSH as part of $i$ ts Fatal Accident Circumstances and Epidemlology (FACE) Project is to determine what factors enabled the fatality to occur. The goal is to learn how such fatalities can be prevented. In this context, whether or not an operation was "In compliance" with existing standards is but one of many variables which may or may not have contributed to the fatality. However, in the course of investigations reported here, it became obvious that full compliance with relevant OSHA standards or application of the NBS/NIOSH recommended work practices would probably have prevented each fatality.

As an obvious first step in preventing such fatalities in the future, we conclude that all such operations should be done only in full compliance with existing OSHA standards. 
Page 4 - Request for Assistance In Preventing Deaths and Injuries from Excavation Cave-ins

TABLE 1

Status of Compliance with Standards (or NBS/NIOSH Recommended Work Practices) in Operations Which Resulted in the Four Fatal Excavation Cave-ins

Relevant OSHA Standards

1. The walls and faces of all excavations in which employees are exposed to danger from moving ground shall be guarded by a shoring system, sloping of the ground, or some other equivalent means. (29 CFR 1926.651

(c))

2. Sides of trenches in unstable or soft material ${ }^{1}, 5$ feet or more in depth, shall be shored, sheeted, braced, sloped, or otherwise supported by means of sufficient strength to protect employees working within them.

(29 CFR 1926.652 (b), Tables $P-1$ and P-2)

3. Excavations (including trenches) adjacent to backfilled areas or subjected to vibrations 1 from rallroads, highway traffic, or operation of machinery shall have additional shoring and bracing precautions taken. (29 CFR 1926.651 (m) and $1926.652(\mathrm{e})$ )

Relevant Recommended Work Practices (NBS/NIOSH)

1. Excavations ${ }^{3}$ from 5 feet to 24 feet $^{4}$ deep in Type $A$ and Type $B$ solls or 5 feet to 15 feet deep in Type $C$ soll shall either be: provided with a shoring system capable of supporting the lateral soll pressure, cut back to the steepest allowable slope for the type of soil, or a combination of both measures. Stable rock is exempt. (Vibration energies have been taken into consideration in the requirement of shoring systems or sloping.)

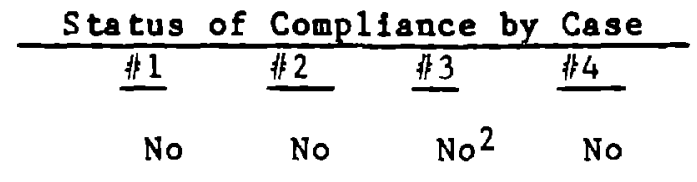

No No No No

No NA No No

1 Subjective, vague, or unclear as to applicability.

2 One hydraulic shore was in use on an intersecting trench.

3 Excavations include trenches; no distinction between them is made as in present OSHA standards.

4 In all excavations deeper than 24 feet, except those in unfractured rock, an engineer (qualifled person) shall determine the shoring, shielding, or sloping requirements.

NA Not applicable 
Page 5 - Request for Assistance in Preventing Deaths and Injuries from Excavation Cave-ins

RECOMMENDATIONS BY NIOSH

The conslstent absence of evidence of compliance with existing regulations in the four incidents described above suggests that employers are either (1) unaware of the existence of the OSHA standards or (2) misinterpreting the requirements of the standards as regards exemptions based on characteristics of the soll.

NIOSH recommends that:

- shoring systems or sloping of the walls be used in all excavations 5 to 24 feet deep in any type of soll, except solid, stable rock.

- approprlate shoring, shlelding, or sloping requirements for all excavations deeper than 24 feet (except those in unfractured rock) be determined by an engineer qualified to make these determinations.

- all employers engaged in excavation activities famlliarize themselves with the provisions of the NBS/NIOSH document (Development of Draft Construction Safety standards for Excavations) and implement them as safe work practices in addition to compllance with the existing OSHA standards.

We urge safety and trade associations, underground utility companies, municipalities and other local governments responsible for underground utility services, as well as state OSHA consultative services to bring these recommendations to the attention of employers engaged in excavations.

Suggestions, requests for additional information on safe work practices, or questions related to this announcement should be directed to Mr. John Moran, Director, Division of Safety Research, 944 Chestnut Ridge Road, Morgantown, West Virglnia 26505, Telephone (304) 291-4595.

Thank you for your help in protecting the lives and health of America's workers.

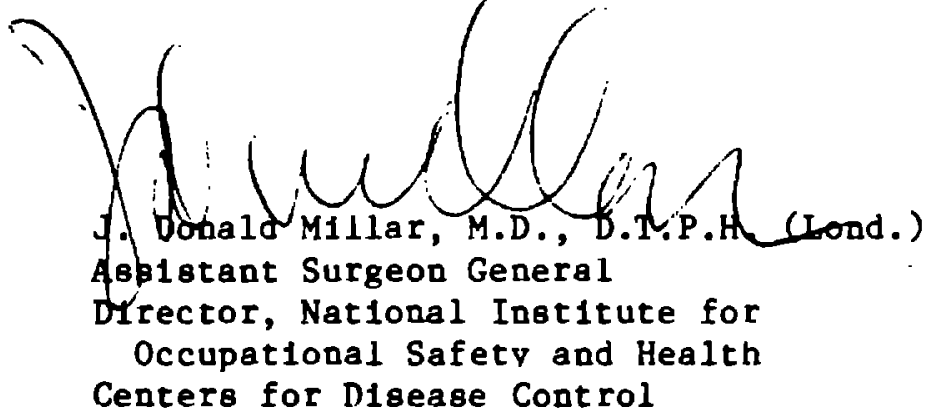


Page 6 - Request for Assistance 1n Preventing Deaths and Injuries from Excavation Cave-ins

\section{REFERENCES}

1. Injury and fatality data for 1976-1981. [Unpublished data from U.S. Department of Labor, Bureau of Labor Statistics, Supplementary Data System].

2. Hinze J. A study of work practices employed to protect workers in trenches, NBSIR No. 79-1942. National Bureau of Standards, December 1979; NTIS PB 80-167-497.

3. Development of draft construction safety standards for excavations. National Institute for Occupational Safety and Health/National Bureau of Standards, NBSIR 83-2693, DHHS (NIOSH) publication no. 83-103, vols 1 and 2. NTIS PB 84-100-569 (Vol. I) and NTIS PB 83-233-353 (Vol. II). 